\title{
PENDEKATAN ICEBERG DALAM PEMBELAJARAN PEMBAGIAN PECAHAN DI SEKOLAH DASAR
}

\author{
Oleh:
}

\author{
Saleh Haji \\ Program Pascasarjana Pendidikan Matematika FKIP Universitas Bengkulu \\ salehhaji25@gmail.com
}

\begin{abstract}
Makalah ini membahas pengaruh pendekatan iceberg pada pembelajaran pembagian pecahan di Sekolah Dasar.Tahapan pendekatan iceberg tersebut sebagai berikut: 1. Orientasi lingkungan secara matematis, 2. Model material, 3. Pembuatan pondasi, dan 4. Matematika formal. Sedangkan topik pembagian pecahan yang dibahas terdiri atas: pembagian bilangan bulat oleh pecahan, pembagian pecahan oleh bilangan bulat, dan pembagian pecahan dengan pecahan. Penggunakan pendekatan iceberg dalam pembelajaran matematika diharapkan dapat mengatasi kesulitan siswa SD dalam memahami materi pecahan khususnya pembagian pecahan.
\end{abstract}

Kata Kunci : Pendekatan Iceberg, Pembagian Pecahan

This paper discusses the influence of iceberg approach to learning division of fractions in school Dasar.Tahapan iceberg approach is as follows: 1. Mathematically oriented environment, 2. Material model, 3. Making foundations, and 4. Formal mathematics. While the division of fractions topics covered consist of: integer division by fractions, division of fractions by integers, and division of fractions by fractions. Use of the iceberg in mathematics learning approach is expected to overcome the difficulties in the elementary school students understand the material fractions in particular the division of fractions.

Key words : Iceberg approach, division of fractions.

\section{Pendahuluan}

Pecahan merupakan salah satu konsep yang mendasar dalam matematika. Konsep ini merupakan salah satu konsep yang dianggap sulit bagi siswa untuk memahaminya, bahkan gurunya (Sukajati, 2008). Ketika dihadapkan dengan operasi pecahan khususnya pembagian, siswa dapat menyelesaikannya dengan menggunakan algoritma tetapi tidak tahu dari mana asalnya algoritma itu dan mengapa algoritma itu digunakan. Misalnya seperti soal berikut ini.

$$
\frac{1}{2}: \frac{1}{3}=\frac{1}{2} \times \frac{3}{1}=\frac{3}{2}=1 \frac{1}{3}
$$


Seringkali siswa mempertanyakan mengapa dalam operasi pembagian, tanda bagi berubah menjadi kali? Kesulitan ini berawal dari penguasaan konsep yang kurang atau tidak memahami tentang konsep pecahan secara menyeluruh. Biasanya guru cenderung menggunakan cara memberikan aturan secara langsung untuk dihafal, diingat, dan diterapkan. Hal tersebut menyebabkan pemahaman matematika siswa kurang bermakna. Selain itu, adanya penekanan pada pengembangan kemampuan pemecahan masalah; berfikir logis, kritis, dan kreatif; serta mengkomunikasikan gagasan secara matematik. Teori belajar yang mendukung terhadap pencapaian kebermaknaan konsep matematika salah satunya adalah konstruktivisme. Teori belajar konstruktivisme menekankan siswa mengkonstruksi sendiri pengetahuan atau konsep yang dipelajarinya.

Salah satu pendekatan pembelajaran yang menganut paham konstruktivisme adalah pendekatan Iceberg. Pendekatan ini didasari oleh teori Realistic Mathematics Education (RME). RME memandang bahwa matematika merupakan aktifitas manusia. RME menekankan kepada konstruksi dari konteks benda-benda konkrit sebagai titik awal bagi siswa guna memperoleh konsep matematika. Benda-benda konkret dan obyek-obyek lingkungan sekitar dapat digunakan sebagai konteks pembelajaran matematika dalam membangun keterkaitan matematika melalui interaksi sosial. Pemanfaatan benda-benda konkret tersebut sebagai suatu awal proses pemodelan oleh siswa. Gravemeijer (1994) menyatakan bahwa model dapat diartikan sebagai jembatan dari masalah real ke dalam matematika formal. Salah satu tipe model realistik memiliki ciri pendekatan buttom-up dimana siswa mengembangkan model sendiri dan kemudian model tersebut dijadikan dasar untuk mengembangkan matematika formalnya. Frans Moerlands (Atmini, 2010) mendiskripsikan tipe realistik tersebut dalam ide gunung es (iceberg) yang mengapung di tengah laut. Dalam model gunung es terdapat empat tingkatan aktivitas, yakni (1) orientasi lingkungan secara matematis, (2) model material, (3) pembuatan pondasi (building stone) dan (4) matematika formal.

\section{Telaah Kepustakaan}

\section{Pendekatan Realistik Mathematics Education (RME)}

Realistic Mathematics Education (RME) merupakan salah satu pendekatan pembelajaran matematika yang berorientasi pada matematisasi pengalaman seharihari dan menerapkannya dalam kehidupan sehari-hari. RME merupakan teori pembelajaran matematika yang dikembangkan di negeri Belanda oleh Freudhenthal pada tahun 1973. Menurut Freudhental matematika merupakan aktivitas manusia (mathematics as a human activity) dan harus dikaitkan dengan realita (de Lang, 1999; Gravemeijer, 1994). Menurut Gravemeijer (1994) dalam pembelajaran matematika yang menggunakan pendekatan RME terdapat tiga prinsip utama yaitu:

1. Penemuan kembali terbimbing (guided reinvention) dan matematisasi progresif (progressive mathematization) 
Menurut prinsip reinvention bahwa dalam pembelajaran matematika perlu diupayakan agar siswa mempunyai pengalaman dalam menemukan sendiri berbagai konsep, prinsip atau prosedur, dengan bimbingan guru. Ketika siswa melakukan kegiatan belajar matematika maka dalam dirinya terjadi proses matematisasi. Terdapat dua macam proses matematisasi, yaitu matematisasi horizontal dan matematisasi vertikal. Matematisasi horizontal merupakan proses penalaran dari dunia nyata ke dalam simbol-simbol matematika. Sedangkan matematisasi vertikal merupakan proses penalaran yang terjadi di dalam system matematika itu sendiri, misalnya : penemuan cara penyelesaian soal, mengkaitkan antar konsep-konsep matematis atau menerapkan rumusrumus matematika.

\section{Fenomenologi didaktis (didactical phenomenology)}

Fenomenologi didaktis adalah para siswa dalam mempelajari konsep-konsep, prinsip-prinsip atau materi lain yang terkait dengan matematika bertolak dari masalah-masalah kontekstual yang mempunyai berbagai kemungkinan solusi, atau setidaknya dari masalahmasalah yang dapat dibayangkan siswa sebagai masalah nyata.

\section{Mengembangkan model-model sendiri (self-developed model)}

Dalam mempelajari konsep-konsep, prinsip-prinsip atau materi lain yang terkait dengan matematika, dengan melalui masalah-masalah konteksual, siswa perlu mengembangkan sendiri model-model atau cara-cara menyelesaikan masalah tersebut. Model-model atau cara-cara tersebut dimaksudkan sebagai wahana untuk mengembangkan proses berpikir siswa, dari proses berpikir yang paling dikenal siswa, ke arah proses berpikir yang lebih formal.

\section{Pendekatan Iceberg dalam $R M E$}

Dalam pembelajaran dengan menggunakan pendekatan RME guru mengarahkan siswa untuk menggunakan berbagai situasi dan kesempatan untuk menemukan kembali konsep-konsep matematika dengan caranya sendiri, konsep matematika diharapkan muncul dari proses matematisasi, yaitu dimulai dari penyelesaian yang berkaitan dengan konteks dan secara perlahan siswa mengembangkan alat dan pemahaman matematik ke tingkat yang lebih tinggi.

Konteks dalam RME merujuk pada situasi dimana soal ditempatkan, sedemikian hingga siswa dapat menciptakan aktivitas matematik dan melatih ataupun menerapkan pengetahuan matematika yang dimilikinya. Konteks dapat pula berupa matematika itu sendiri, sepanjang siswa dapat merasakannya sebagai hal riil. Frans Moerland (Atmini, 2010) memvisualisasikan proses matematisasi dalam pembelajaran RME sebagai proses pembentukan gunung es (iceberg). Proses pembentukan gunung es di laut selalu dimulai dari bagian dasar di bawah 
permukaan laut dan seterusnya akhirnya terbentuk puncak gunung es yang muncul di atas permukaan laut. Bagian dasar gunung es lebih luas dari pada puncaknya, dengan demikian konstruksi gunung es tersebut menjadi kokoh dan stabil. Proses ini diadopsi pada proses matematisasi dalam matematika realistik, yaitu dalam pembelajaran selalu diawali dengan matematisasi horizontal kemudian meningkat sampai matematisasi vertikal. Matematisasi horizontal lebih ditekankan untuk membentuk konstruksi matematika yang kokoh sehingga matematisasi vertikal lebih bermakna bagi siswa. Dalam model gunung es terdapat empat tingkatan aktivitas, yakni (1) orientasi lingkungan secara matematis (mathematical world orientation), (2) model material, (3) pembuatan pondasi (building stone) dan (4) matematika formal. Contoh ide iceberg dalam pembelajaran perkalian adalah sebagai berikut (Atmini, 2010):

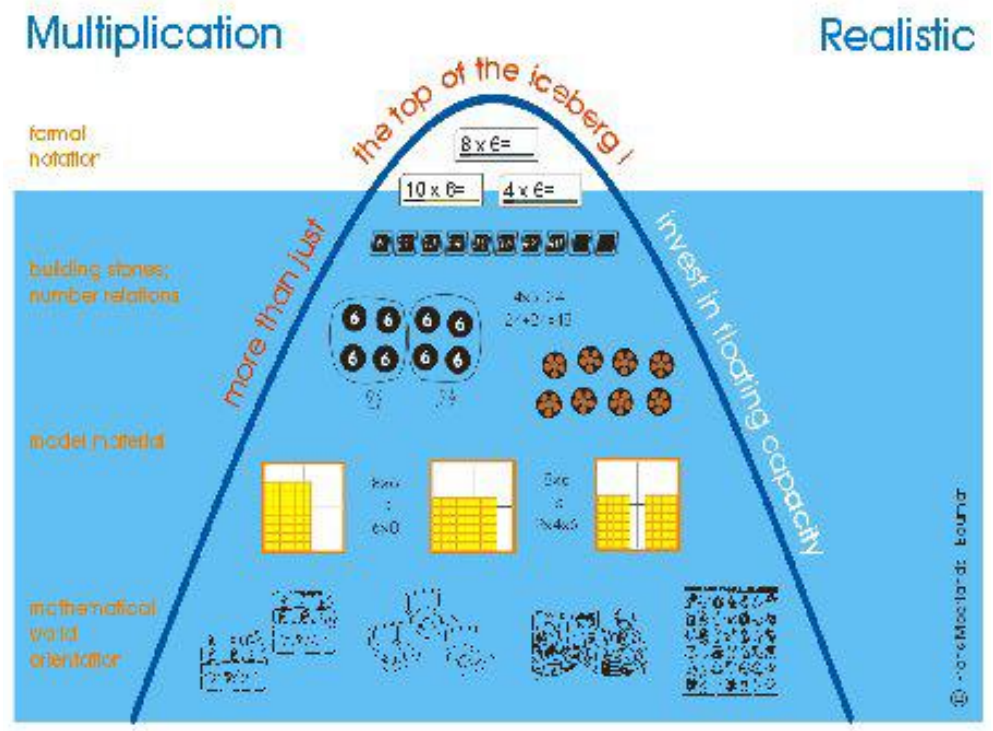

\section{Penyajian Materi Pembagian Pecahan dengan Pendekatan Iceberg}

Materi pecahan mulai dikenalkan siswa di kelas IV Sekolah dasar (SD) semester 2, namun pembagian pecahan mulai diberikan di kelas V SD semester 2. Standar kompetensi yang akan dikembangkan dalam pembelajaran pecahan kelas $\mathrm{V}$ adalah mengenal dan menggunakan pecahan dalam pemecahan masalah, sedangkan kompetensi dasar yang berkaitan dengan pembagian adalah mengalikan dan membagi berbagai bentuk pecahan (Depdiknas, 2006). Dari kompetensi dasar tersebut diuraikan indikator sebagai berikut. Siswa mampu membuat algoritma 1) 
pembagian bilangan bulat oleh pecahan; 2) pembagian pecahan oleh bilangan bulat; dan 3) pembagian pecahan dengan pecahan.

\section{Pembagian Bilangan Bulat oleh Pecahan}

Konteksnya adalah membuat pizza dengan batang keju.

Ani akan membuat pizza. Setiap pizza membutuhkan 3/4 batang keju dan Ani memiliki 5 batang keju. Berapa banyak Ani dapat membuat pizza?

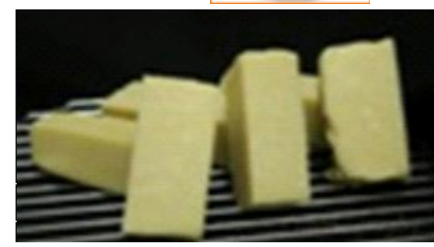

Strategi sederhana yang mungkin digunakan siswa adalah sebagai berikut.

\section{Strategi 1}

Membuat persegi panjang mewakili satu batang keju dan membuat partisi setiap persegi (mewakili satu batang keju) menjadi empat partisi. Kemudian dibuat kelompok $3 / 4$ sehingga dapat ditentukan berapa banyak pizza dapat dibuat. Untuk menggambarkannya dapat 2 cara (Anoname, 2011).

\section{Cara 1}

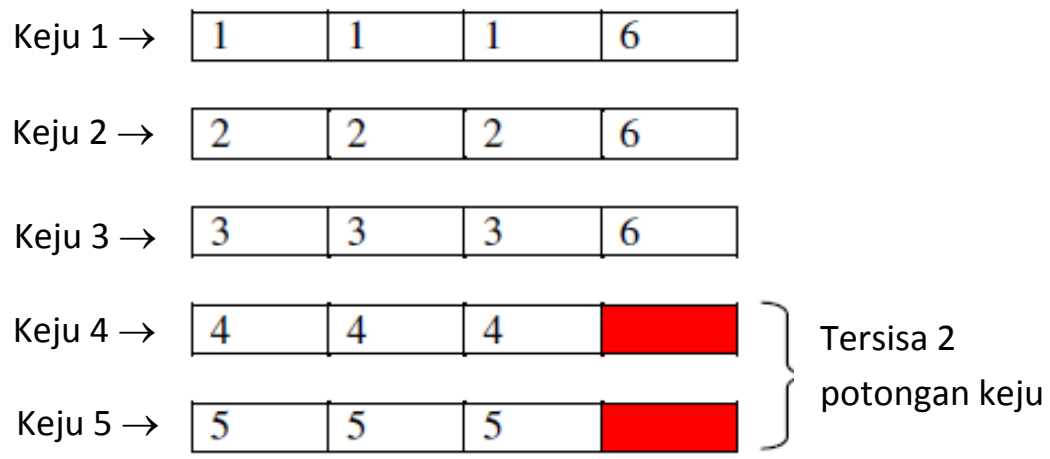

Cara 2

\begin{tabular}{|c|c|c|c|c|}
\hline Keju $1 \rightarrow$ & 1 & 1 & 1 & 2 \\
\hline Keju $2 \rightarrow$ & 2 & 2 & 3 & 3 \\
\hline Кeju $3 \rightarrow$ & 3 & 4 & 4 & 4 \\
\hline Keju $4 \rightarrow$ & 5 & 5 & 5 & 6 \\
\hline Keju $5 \rightarrow$ & 6 & 6 & & \\
\hline
\end{tabular}


Terdapat dua bagian tersisa yang mewakili $\frac{2}{3}$ pizza lain (karena pizza masing-masing hanya membutuhkan tiga potongan).

Jadi hasilnya adalah 6 pizza $+\frac{2}{3}$ pizza $=6 \frac{2}{3}$ pizza

\section{Strategi 3}

Model garis bilangan dapat digunakan sebagai strategi lain untuk membantu siswa. Jika kita membuat daftar garis bilangan dari 0 sampai 5 maka partisi setiap bagian menjadi empat, siswa dapat melingkari kelompok 3/4 dan kemudian mereka akan melihat dua bagian yang tersisa (Anoname, 2011).

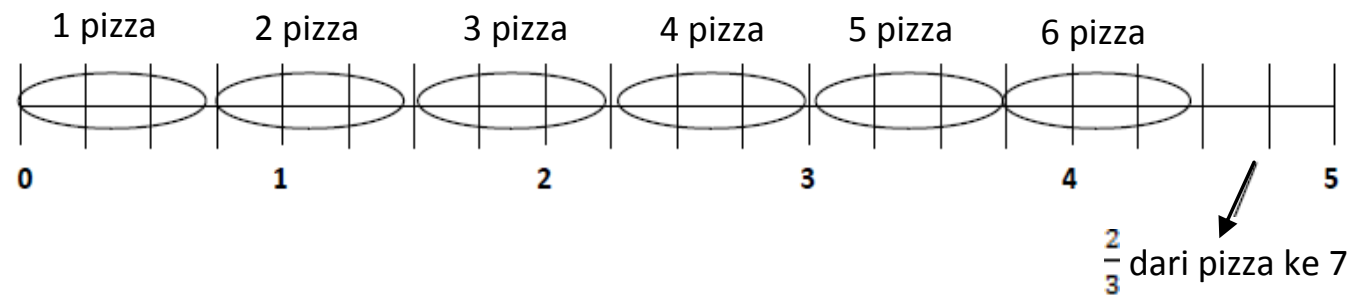

Tabel rasio juga dapat digunakan sebagai model untuk memecahkan masalah pizza dari batang keju. Kita mulai dengan pelabelan dan skala batang $3 / 4$ untuk 1 pizza sampai kita mencapai 5 batang keju. Berikut adalah strategi yang mungkin siswa lakukan dengan menggunakan tabel rasio (anoname, 2011).

\begin{tabular}{|c|c|c|c|c|c|c|}
\hline $\begin{array}{l}\text { Banyak } \\
\text { pizza }\end{array}$ & 1 & 2 & 4 & 6 & $\frac{2}{3}$ & $6+\frac{2}{3}=6 \frac{2}{3}$ \\
\hline $\begin{array}{l}\text { Banyak } \\
\text { batang keju }\end{array}$ & $\frac{3}{4}$ & $1 \frac{1}{2}$ & 3 & $4 \frac{1}{2}$ & $\begin{array}{c}\text { Sisa batang } \\
\text { keju } \frac{1}{2}\end{array}$ & 5 \\
\hline
\end{tabular}

Dengan demikian akan diperoleh hasil bahwa:

$5: \frac{3}{4}=6 \frac{2}{3}$ atau $5: \frac{3}{4}=\frac{20}{3}$

Bandingkan dengan $5 \times \frac{4}{3}=\frac{20}{3}=6 \frac{2}{3}$ 


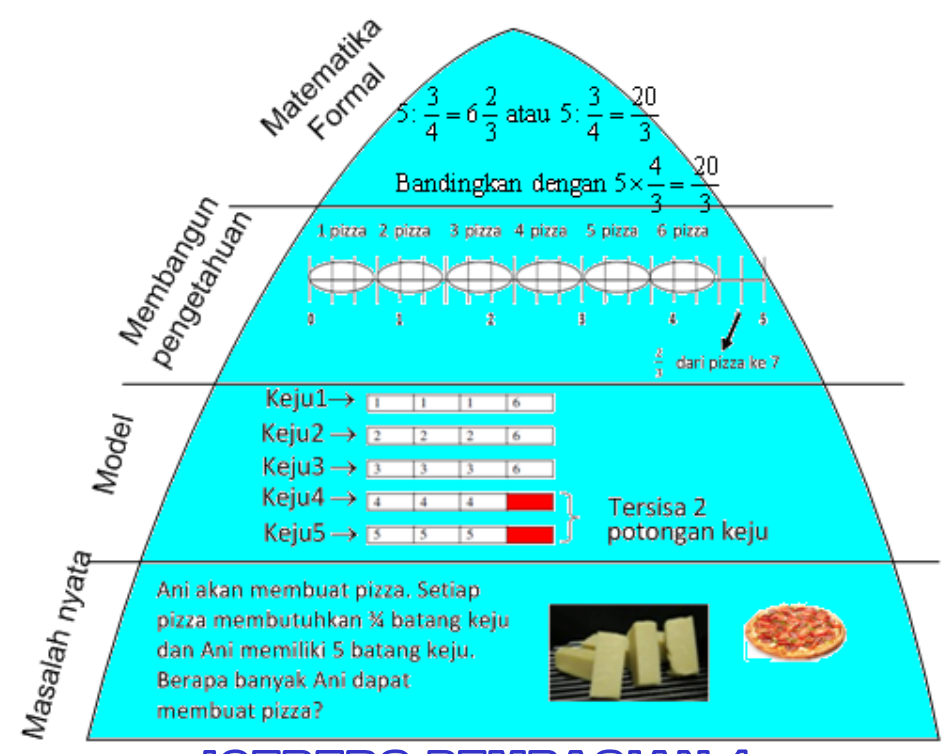

ICEBERG PEMBAGHAN U

\section{Pembagian Pecahan oleh Bilangan Bulat}

Konteksnya adalah pita dan bingkai foto.

ibu memiliki pita sepanjang $\frac{2}{3}$ meter. Ibu ingin membagi pita tersebut kepada 4 orang anak perempuannya untuk menghias bingkai foto masing-masing. Berapakah panjang pita yang diperoleh masing-masing anak?.
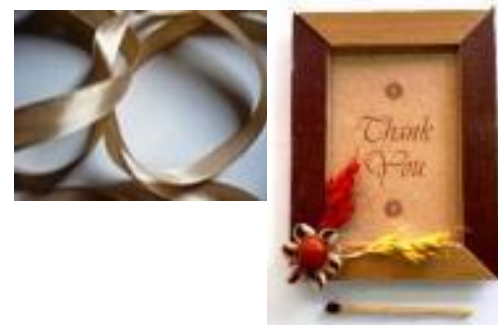

Model yang mungkin digunakan siswa dengan menggunakan diagram pita. Pita tersebut dibagi menjadi 3 bagian dan 2 bagian diarsir. Bagian yang diarsir menunjukkan $\frac{2}{3}$ (panjang pita). Kemudian bagian yang diarsi tersebut dibagi lagi menjadi 4 bagian yang sama untuk melihat bahwa setiap anak mendapatkan $\frac{1}{6}$ meter. Model tersebut dapat digambar sebagai berikut.

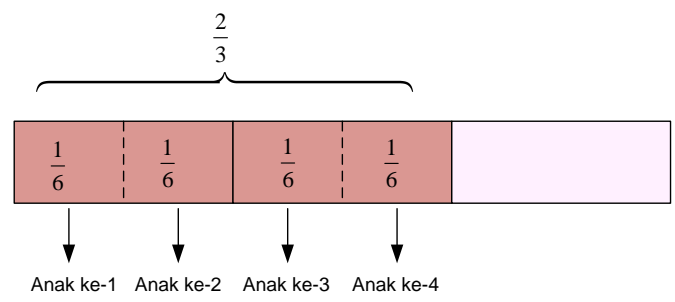


Strategi lain dapat menggunakan garis bilangan, yaitu:

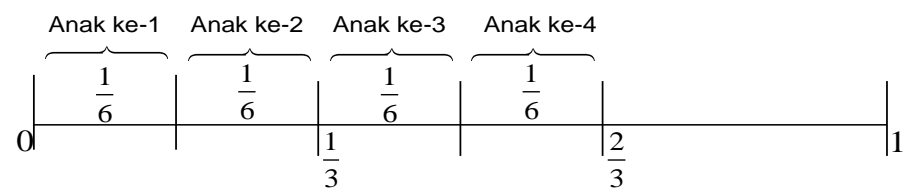

Dari model dan strategi tersebut akan diperoleh hasil bahwa: $\frac{2}{3}: 4=\frac{1}{6}$. Bandingkan dengan $\frac{2}{3} \times \frac{1}{4}=\frac{1}{6}$

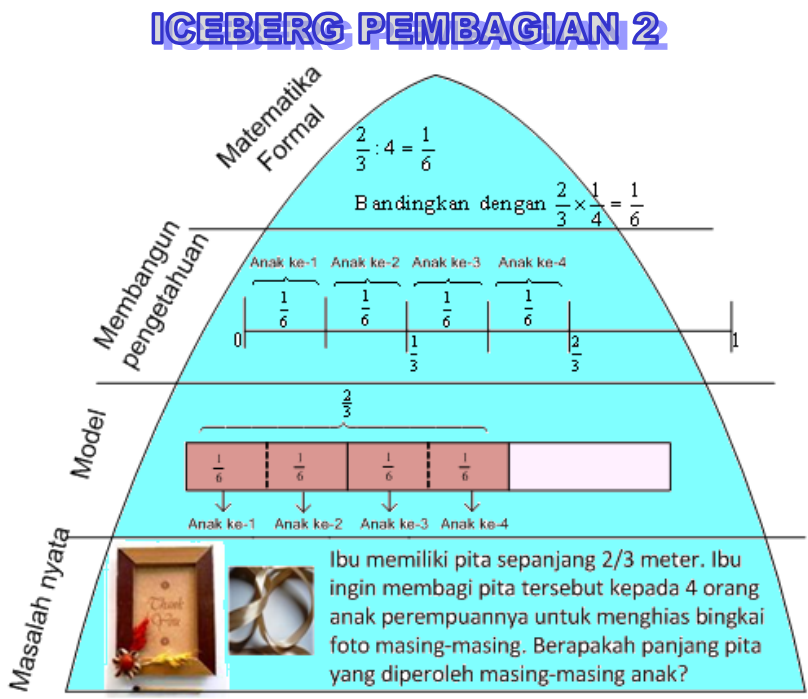

\section{Pembagian Pecahan dengan Pecahan}

Konteksnya adalah membuat cake dengan terigu.

Dibutuhkan $\frac{3}{8} \mathrm{~kg}$ terigu untuk membuat satu buah cake. Berapa banyak cake yang dapat dibuat dari $\frac{1}{2}$ kg terigu?

Strategi atau model yang mungkin digunakan siswa adalah: 


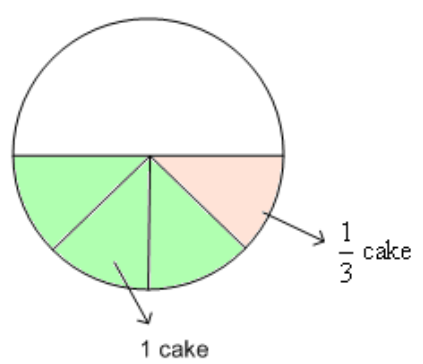

Garis bilangan dapat juga digunakan sebagai strategi atau model untuk menyelesaaikan masalah ini, yaitu:

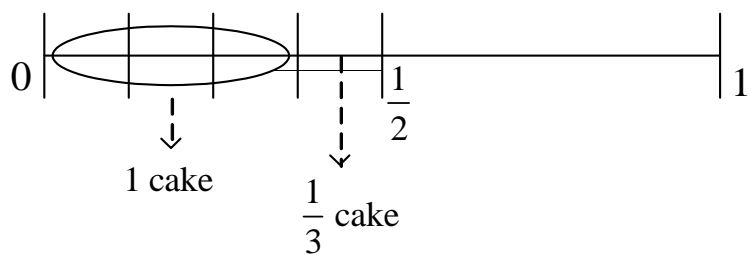

Dari model dan strategi tersebut akan diperoleh hasil bahwa:

$\frac{1}{2}: \frac{3}{8}=1 \frac{1}{3}$ atau $\frac{1}{2}: \frac{3}{8}=\frac{4}{3}$ Bandingkan dengan $\frac{1}{2} \times \frac{8}{3}=\frac{4}{3}$

\section{ICEBERG PENBAGIAN 3.}

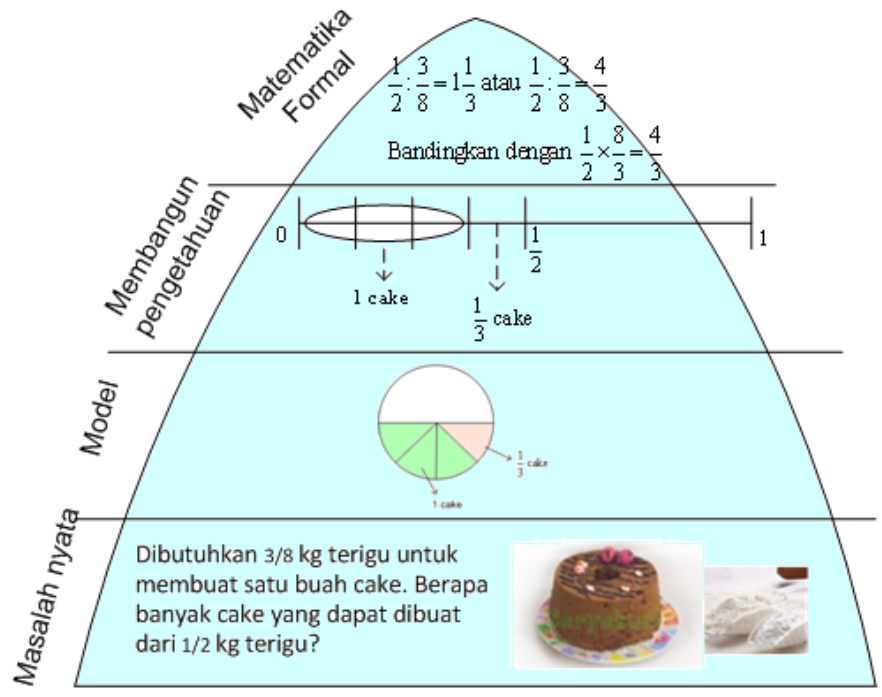

Di akhir pembelajaran pembagian pecahan dengan iceberg tersebut, siswa akan menemukan sendiri algoritma pembagian sebagai berikut. 


$$
\begin{aligned}
& a: \frac{b}{c}=a \times \frac{c}{b}=\frac{a \times c}{b} \\
& \frac{b}{c}: a=\frac{b}{c} \times \frac{1}{a}=\frac{b}{a \times c} \\
& \frac{a}{b}: \frac{c}{d}=\frac{a}{b} \times \frac{d}{c}=\frac{a \times d}{b \times c}
\end{aligned}
$$

\section{Penutup}

Pembagian pecahan merupakan salah satu konsep yang dianggap sulit bagi siswa untuk memahaminya. Siswa dapat menyelesaikan soal dengan menggunakan algoritma pembagian pecahan tetapi tidak tahu dari mana asalnya algoritma itu dan mengapa algoritma itu digunakan. Biasanya guru cenderung menggunakan cara memberikan aturan secara langsung untuk dihafal, diingat, dan diterapkan. Pendekatan Realistic Mathematics Education (RME) menawarkan suatu proses pembelajaran yang memandang bahwa matematika merupakan aktifitas manusia, sehingga siswa melalui konteks benda-benda konkrit mengkonstruksi sendiri matematika secara formal. Salah satu tipe model realistik adalah ide gunung es (iceberg) yang meliputi empat tingkatan aktivitas, yakni (1) orientasi lingkungan secara matematis, (2) model material, (3) pembuatan pondasi (building stone) dan (4) matematika formal. Terdapat tiga penyajian iceberg, yaitu pembagian bilangan bulat oleh pecahan, pembagian pecahan oleh bilangan bulat, dan pembagian pecahan dengan pecahan. Diharapkan dengan menggunakan pendekatan iceberg ini, kesulitan siswa SD terhadap pemahaman materi pecahan khususnya pembagian pecahan dapat diminimalisir.

\section{DAFTAR PUSTAKA}

Anoname (2011). Division of Fractions: An Iceberg Inspired Learning Trajectory.[online]. Tersedia:http://www.fisme.science.uu.nl. [12 Oktober 2012].

Atmini. (2010). Pembelajaran Matematika dengan Pendekatan Matematika Realistik (PMR).

[Online]. Tersedia:

Files/Tmp/Makalah\%20PMRI\%202010.Pdf. [12 Oktober 2012].

De Lange, J. (1999). Mathematics, Insight and Meaning. Utrecht: OW \& CO.

Depdiknas. (2006). Permendiknas No. 22 Tentang Standar Isi Untuk Satuan Pendidikan Dasar Dan Menengah (Lampiran). Jakarta: Depdiknas.

Gravemeijer, K.P.E. (1994). Developing Realistic Mathematics Education. Utrecht: Freudenthal Institute.

Sukajati (2008). Operasi Penjumlahan Pecahan di SD Menggunakan Berbagai Media. Yogyakarta: PPPPTK Matematika. 